\title{
Ecological and biological features of Triglochin maritima L. in the biotopes of the littoral zone with different degree of flooding on the coast of the White Sea
}

\author{
Anzhella V. Sonina*, Elena N. Terebova, Tamara Yu. Dyachkova, Kira \\ V. Morozova, Nadezhda A. Elkina \\ Petrozavodsk State University, Department of Botany and Plant Physiology, pr. Lenina, \\ 33, Petrozavodsk, Russia
}

\begin{abstract}
The study of Triglochin maritima L. was carried out on the Pomor (western) coast of the

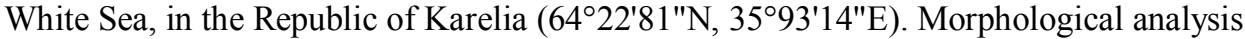
of aboveground and underground parts of the clones was performed on virginal plants. Anatomical analysis of leaf sheaths of the current year shoots, rhizomes and adventitious roots was carried out. The viability of pollen was assessed by determining the relative share of normally developed and malformed pollen grains. The content of heavy metals was determined in the soil, sea water and plant samples. The study was carried out on a model transect in the littoral zone on three test plots representing the lower littoral; the middle and the upper littoral zones. Adaptation to wave and storm impact was manifested in a well-developed system of underground organs. In the lower littoral, underground part surpasses the aboveground vegetative organs in terms of the mass and the formation of mechanical tissues. This allows the plants to anchor stronger in the substrate. Pollen analysis confirmed the adaptability of $T$. maritima plants to the conditions of the lower littoral by a high percentage of normal and, consequently, fertile pollen, which ensures sexual reproduction of the species. T. maritima can be considered as a Fe hyperaccumulator as the plant accumulates very high levels of Fe $\left(22-34 \mathrm{~g} \mathrm{~kg}^{-1}\right)$, especially in the lower and middle littoral zones, both in underground and aboveground organs. The ability of $T$. maritima plants to actively deposit metals was revealed on the basis of the coefficient of biological absorption of metals and makes it possible to suggest potential possibility of using the species in phytoremediation technologies on coastal territories.
\end{abstract}

Key words: anatomy of vegetative organs, Triglochin maritima, clone morphology, pollen grain, heavy metal, coefficient of biological absorption, hyperaccumulator

DOI: $10.5817 / \mathrm{CPR} 2021-2-16$

Received July 5, 2021, accepted December 29, 2021.

*Corresponding author: A. V. Sonina < angella_sonina@mail.ru>

Acknowledgements: The work was supported by the project of the State Assignment of the Ministry of Science and Higher Education of the Russian Federation (№ 0752-2020-0007). 


\section{Introduction}

Considerable attention nowadays is paid to the Arctic region (Minin 2014). Great prospects for economic development in the Arctic raise active discussion in the scientific community and stimulate multidisciplinary research, including studies of the vulnerability of different types of ecosystems and their components. The study of coastal ecosystems is necessary due to offshore hydrocarbon activity in the Arctic marine area (Dmitrievsky et al. 2015). Along the White Sea coast, tides create very dynamic and unstable environment so that littoral biota, including phototrophic organisms, has to adapt to it. The numbers of dominant vascular plants on the coasts of northern seas are much less compared to southern seas. The biology and ecology

\section{Material and Methods}

T. maritima is a circumboreal temperate arctic species (Tsvelev 2000), often dominating in plant communities of coastal and marsh ecosystems. The biological feature of the species is the formation of a clonal biomorph, which ensures high tolerance to unstable environmental conditions. T. maritima is a herbaceous perennial with a long and branched rhizome, sometimes forming a rhizome ring protruding above the substrate. On the rhizome, ramets (shoots of vegetative origin) with fleshy basal narrow-linear leaves, 2-5 mm wide, develop annually. A mass is also formed from the sheaths of last year dead leaves. Peduncles are up to $45-50 \mathrm{~cm}$. The study was carried out on the Pomor (western) coast of the White Sea, in the vicinity of the village Rastnavolok of the Belomorsk region (Republic of Karelia; $64^{\circ} 22^{\prime} 81^{\prime \prime N}, 35^{\circ} 93^{\prime} 14^{\prime \prime E}$ ) (Fig. 1). A model transect (MT) $500 \mathrm{~m}$ long and $5 \mathrm{~m}$ wide was established from the water edge (lower littoral) to the bedrock coast (supralittoral) during the period of complete low tide. This part of the coast is the mouth of a small stream, widened of the halophyte Triglochin maritima L. has been studied (Davy and Bishop 1991, Buzgo et al. 2006, Bobrov 2018, Buffington et al. 2020, Edge et al. 2020). On the coast of the White Sea, cenopopulations of this species were studied on silty and sandy-pebble substrates in the diurnal dynamics of flooding (Sergienko et al. 2017). However, in general, the ecological and biological features of the species ensuring the successful survival and reproduction under dynamic conditions of the littoral zone are much wider and are still poorly understood. The purpose of this work was to evaluate ecological and biological characteristics of $T$. maritima on the White Sea coast in the littoral biotopes with different degree of flooding.

towards the sea. The estuarine zone, $180 \mathrm{~m}$ wide, reached a small rocky ridge covered with sandy-silty sediments. The central part of the transect was a slightly silted depression overgrown with fragmentary clumps of coastal plants. Water salinity did not exceed $17 \%$. The transect was divided into three zones with different types of substrate and floristic composition. The $1^{\text {st }}$ zone located in the lower littoral, at the water edge and protected by a stone ridge, was inhabited by four plant species: T. maritima, Tripolium pannonicum (Jacg.) Dobrocz., Plantago maritima L. and Glaux maritima L. (cover up to $1 \%$ ), with a predominance of $T$. maritima $(10 \%)$ and $P$. maritima $(10 \%)$. In the $2^{\text {nd }}$ zone (the middle littoral), T. maritima also dominated in the communities with Ruppia maritima L. and Carex mackenziei V. Krecz. In the $3^{\text {rd }}$ zone (the upper littoral, near the bedrock coast), T. maritima was a codominant in communities with Bolboschoenus maritimus (L.) Palla and T. pannonicum. 
The study was carried out on three test plots (TP). TP1 (the $1^{\text {st }}$ zone) was located at the water edge on the lower littoral; $300 \mathrm{~m}$ in length; substrate - clay:sand / $60: 40 \%$. TP2 $\left(2^{\text {nd }}\right.$ zone $)$ was located in the central part of the transect in the middle littoral; $20 \mathrm{~m}$ in length; substrate - clay: sand:pebbles / 10:10:80). TP3 ( $3^{\text {rd }}$ zone $)$ was located near the bedrock in the upper littoral; $35 \mathrm{~m}$ in length; substrate - clay: sand:pebbles / 20:20:60).

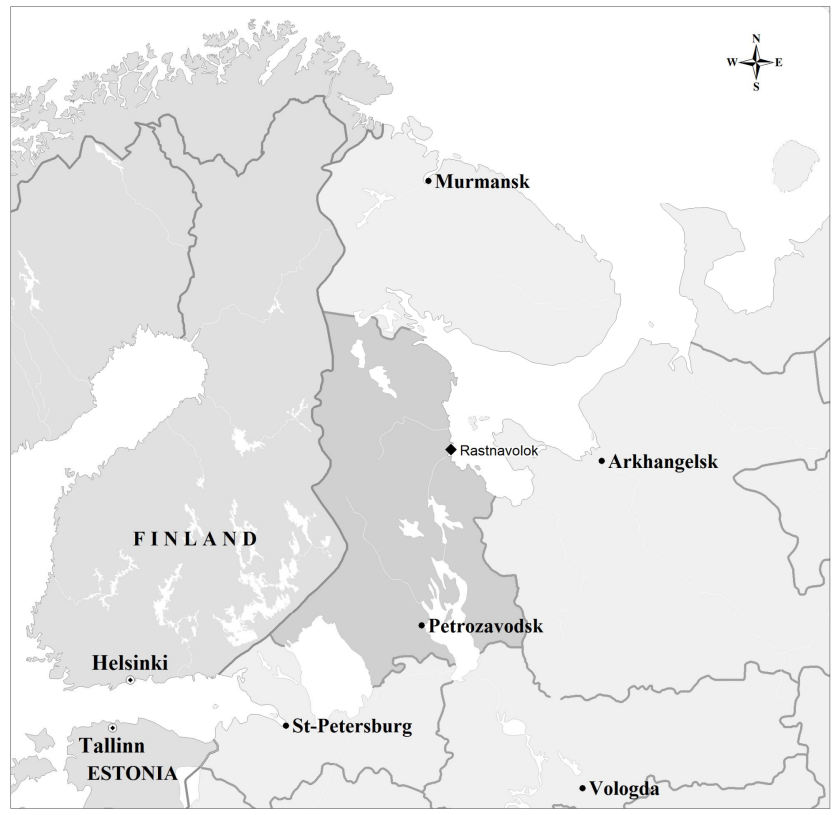

Fig. 1. Map of the study area.

\section{Morphological and anatomical analysis}

The clones from three zones of the transect were separated into ramets. The number of clones in a ramets and fresh weight of the aboveground and underground parts of the clones were determined. Morphological analysis was performed on virginal (adult vegetative) shoots $(n=10)$. The shoot height, number and length of leaves, and length of adventitious roots were measured. To determine the anatomical parameters of vegetative organs they were fixed in $70 \%$ ethanol. Leaf sheaths of shoots of the current year (from the $1^{\text {st }}, 2^{\text {nd }}$ and $3^{\text {rd }}$ zones), rhizomes (from the $1^{\text {st }}$ and $2^{\text {nd }}$ zones), and adventitious roots (from the $1^{\text {st }}, 2^{\text {nd }}$ and $3^{\text {rd }}$ zones) $(n=30)$ were analyzed. Anatomical structures were measured on cross sections by a MIKMED-6 light microscope (LOMO, Russia). The assessment of the morphometric parameters of sheath mesostructure was carried out according to the method of Mokronosov and Borzenkova (1978). The volume of cells and intercellular spaces in tissues of vegetative organs was determined using the ellipsoid formula, as the ratio $\mathrm{L} / \mathrm{d}$ is less than 2.5 :

$$
\mathrm{V}=4 / 3 \pi * \mathrm{~L} / 2 *(\mathrm{~d} / 2) 2, \quad \text { Eqn. } 1
$$

where $\mathrm{L}$ is the cell length, $\mathrm{d}$ is the cell width or diameter (Borzenkova and Khramtsova 2006). 


\section{Pollen analysis}

Anthers were collected from 10 plants (one flower per plant) in each zone $(n=600)$. Pollen viability was assessed using an acetocarmine test. For microscopic analysis, anthers were removed from fixed flowers and broken mechanically in a drop of acetocarmine on a glass slide (Pausheva

\section{Chemical analysis}

In the middle part of each SP, 3 soil samples and samples of 5 plants were collected to determine the content of heavy

\section{Measurements of heavy metals}

The concentration of $\mathrm{Fe}, \mathrm{Cu}, \mathrm{Zn}, \mathrm{Pb}$, $\mathrm{Mn}$ and $\mathrm{Ni}$ was estimated using the atomic absorption spectrophotometer AA-7000 with a flame atomizer, Shimadzu 7000 (Japan). The samples $(0.2 \mathrm{~g})$ were first dissolved in a mixture of concentrated acids $\left(\mathrm{HNO}_{3}, \mathrm{HCl}\right.$, in the ratio 3:1) in the microwave digestion system (Speedwave four, Berghof, Germany). The heavy metal concentrations were measured at the Center of Shared Equipment Use «Analytical laboratory» of Forest Research Institute of the Karelian Research Centre of RAS (ISO
1980). The relative share of normally developed and malformed pollen grains was determined using a light microscope Axio Scope A1 (Carl Zeiss, Germany) at a 400 magnification. The descriptions of pollen grains given in the literature (Pires and Medeanic 2006) served as a reference.

metals in soil and plant samples (from adventitious roots and aboveground organs).

11466:1995, NBN EN 13657:2002, ISO 11407:1998, ISO 20280:2007). All measurements were done in triplicate. The coefficient of biological absorption (CBA) of $\mathrm{Fe}, \mathrm{Cu}, \mathrm{Zn}, \mathrm{Pb}, \mathrm{Mn}$ and $\mathrm{Ni}$ by a whole plant was calculated as a ratio of the metal content in the plant (in adventitious roots and aboveground organs) to the metal content in the soil and sea water (Polynov 1956, Batalov et al. 1991). The higher the value of CBA, the more intensively the element is absorbed by the plant (Polynov 1956).

\section{Measurements of salinity and the content of chemical elements in soil and water}

Field seawater salinity was determined using a refractometer RHS-10ATC (Russia). The degree of soil salinity was estimated by the mass fraction (\%) of dry (dense) organic extract residue, the content of matter was determined by the method according to I.V. Tyurin (Vorobeva 2006). Total nitrogen was determined using ulti-

Statistical analysis of the data obtained was carried out using Microsoft Excel, Statgraphics for Windows. The significance mate CHNS analyzer (PerkinElmer's 2400 Series II CHNS/O, USA). The phosphorus content was determined by the ammonium-molybdate method using spectrophotometer (OKB Spektr SF-2000, Russia). Labile potassium was determined by flame atomic absorption spectrophotometer (Shimadzu AA 7000, Japan) (Tan 2005).

of the differences in the parameters was assessed by the Student's t-test at $\mathrm{P}=95 \%$. 


\section{Results}

\section{Morphological and anatomical analysis}

According to the phytocoenotic biomorph, T. maritima belongs to the implicit polycentric type, characterized by the fact that adult plants have several closely located growth centres, which were difficult to distinguish. The phytomass is distributed over the area occupied by an individual relatively evenly. The general view of the clones within the transect is shown in Fig. 2.

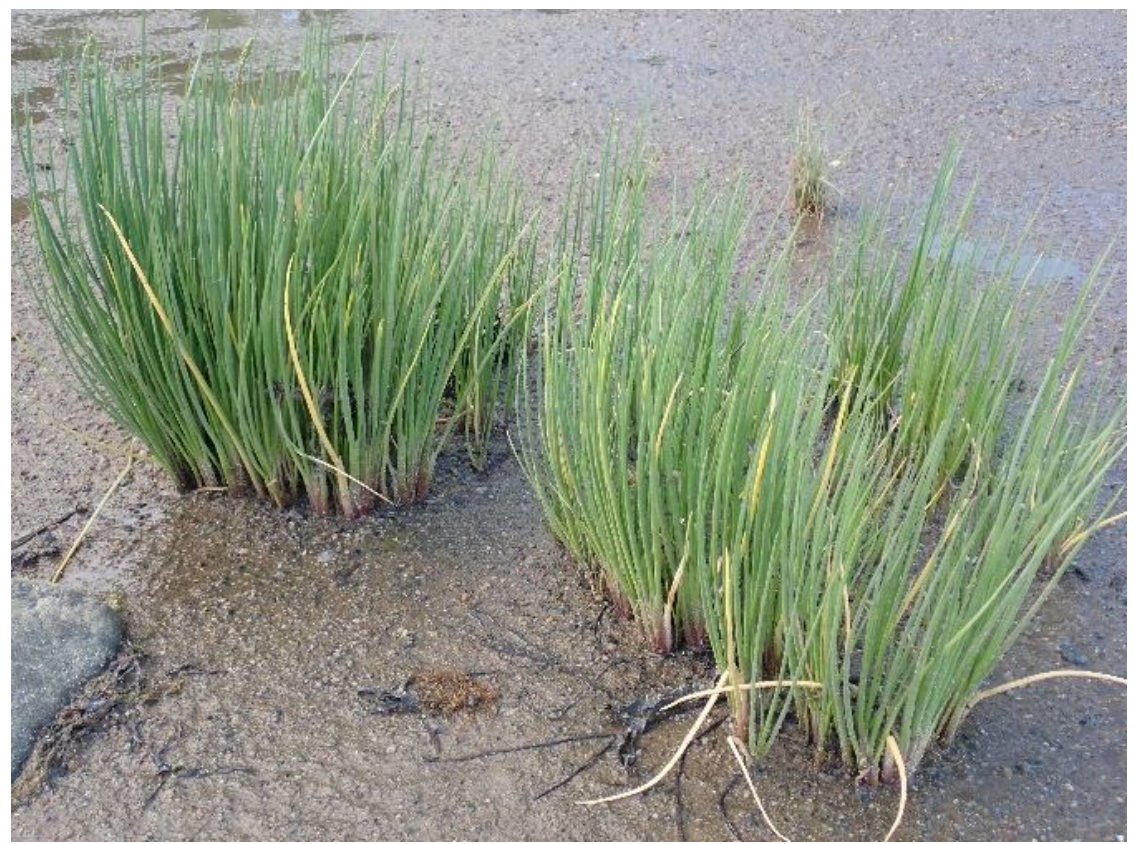

Fig. 2. Triglochin maritima on the model transect (foto by A.V. Sonina).

The aboveground part of the clone is represented by a set of closely located rosette shoots with two-row leaves with fleshy widened sheaths. The underground part of the clone consists of a strong rhizome with numerous adventitious roots and dead leaf sheaths of the last year (see Fig. 3).

The clone growth and biomass accumulation occur due to the branching of short rhizome (in a "net" mode) with a dense "brush" of firmly and closely seated sheaths of dead leaves, a large number of adventitious roots and annually formed ramets. In each zone, the biomass of the clone underground part (rhizome with adventitious roots and sheaths of dead leaves) exceeded the biomass of the aboveground part by 1.5-2 times (Table 1 ). The highest total clone biomass was recorded in the $3^{\text {rd }}$ zone while the lowest biomass was fixed in the $1^{\text {st }}$ zone at the water edge. The same order was observed for the number of ramets in the clone. Their number increased from the water edge to the upper littoral zone. 


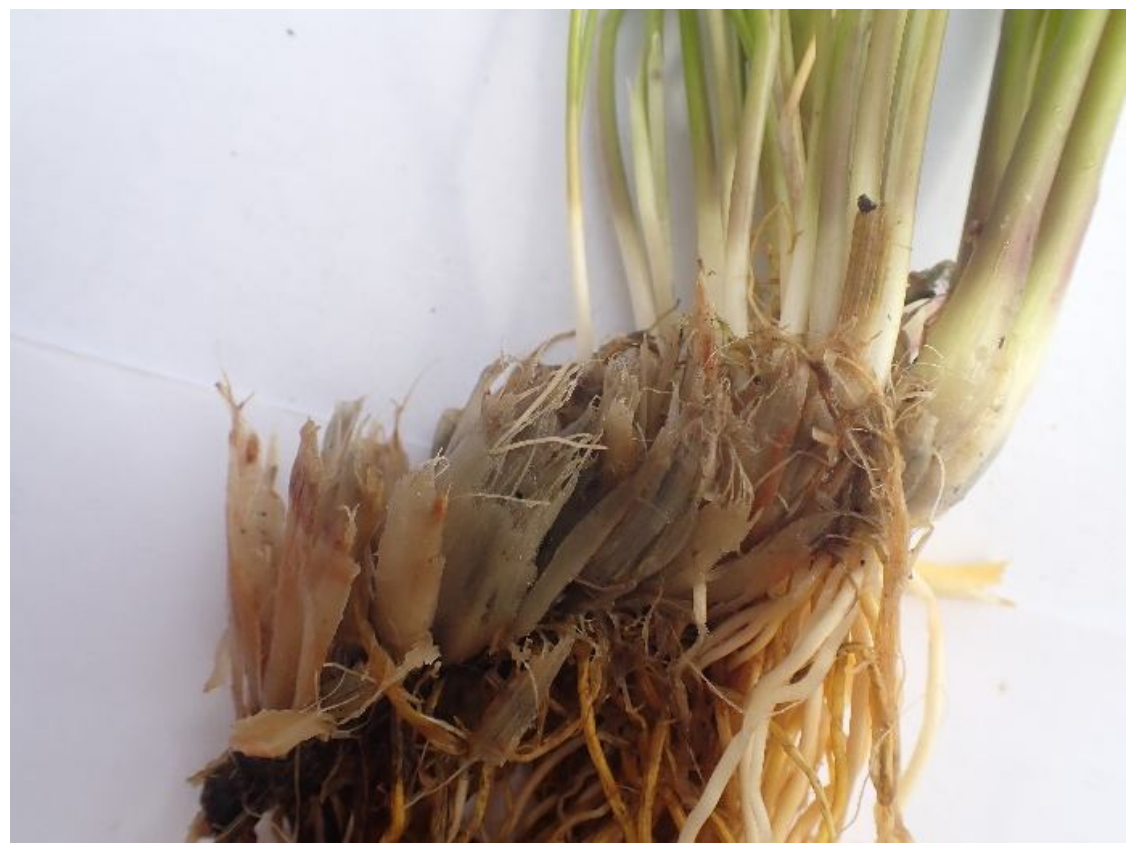

Fig. 3. Part of the clone with a rhizome, adventitious roots, sheaths of last year dead leaves and aerial shoots of the current year (foto by A.V. Sonina).

\begin{tabular}{|l|c|c|c|}
\hline \multirow{2}{*}{ Parameters } & \multicolumn{3}{|c|}{ Zone } \\
\cline { 2 - 4 } & $\mathbf{1}$ & $\mathbf{2}$ & $\mathbf{3}$ \\
\hline Number of ramets in clone, pcs. & 24 & 75 & 116 \\
\hline $\begin{array}{l}\text { Fresh weight of the clone } \\
\text { aboveground part, g. }\end{array}$ & 64.5 & 179.4 & 257.2 \\
\hline $\begin{array}{l}\text { Fresh weight of the clone } \\
\text { underground part, g. }\end{array}$ & 92.3 & 355.0 & 340.0 \\
\hline
\end{tabular}

Table 1. General characteristics of the Triglochin maritima clones.

Virginile shoots increased along the transect from $28-35 \mathrm{~cm}$ in the $1^{\text {st }}$ zone to $38-40 \mathrm{~cm}$ in the $3^{\text {rd }}$ zone. The shoot height in the $1^{\text {st }}$ zone significantly differed from those in the $2^{\text {nd }}$ and $3^{\text {rd }}$ zones (Fig. 4). The number of leaves on the shoots was significantly higher in the $2^{\text {nd }}$ zone than in the $1^{\text {st }}$ and $3^{\text {rd }}$ zones, where the same number of leaves was recorded. The leaf length was the smallest in the $1^{\text {st }}$ zone. There were no significant differences in the length of adventitious roots in different zones, al- though there was a tendency to its increase towards the $1^{\text {st }}$ zone (Fig. 4).

In general, T. maritima clones growing in the lower littoral zone (the $1^{\text {st }}$ zone) showed the lowest biomass, smaller number and morphological parameters of ramets (with the exception of adventitious roots length), which may indicate adaptation of plants to specific growth conditions. These plants need to be better anchored being in the zone of the greatest wave impact. 


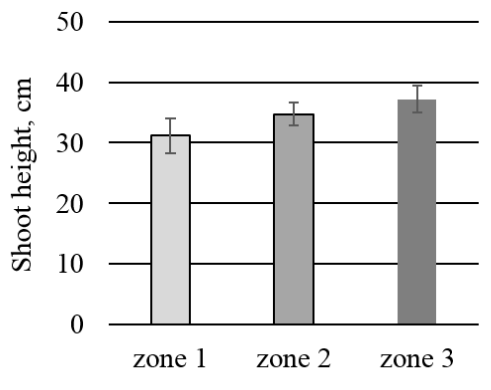

$\mathbf{a}$

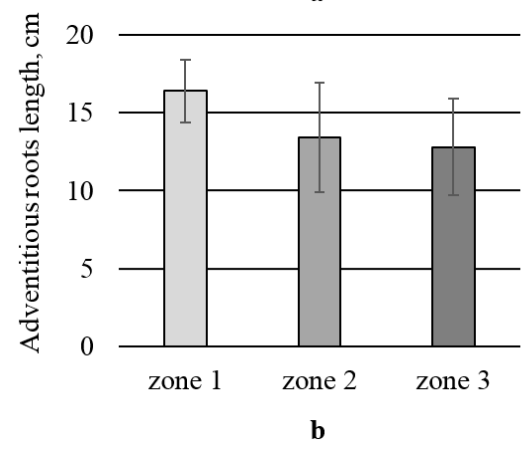

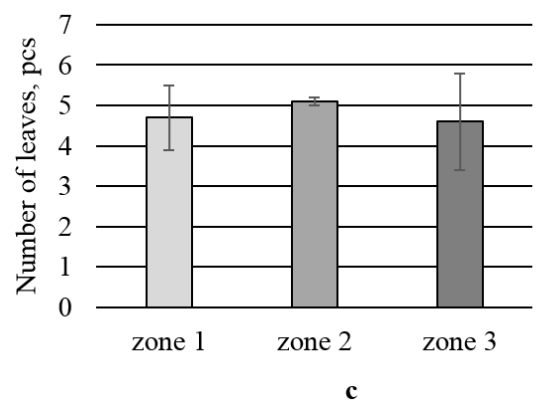

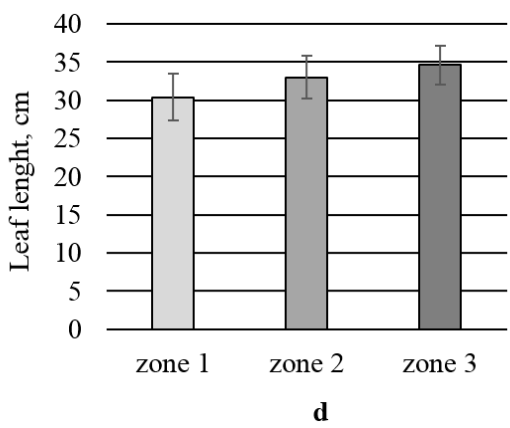

Fig. 4. Morphology of plants from different littoral zones: $\mathbf{a}$ - shoot height, $\mathbf{b}$-adventitious roots length, $\mathbf{c}$ - number of leaves, $\mathbf{d}$ - leaf length.

The current year leaf sheaths were thicker in the $1^{\text {st }}$ zone 1 (Table 2). Towards the upper littoral (the $3^{\text {rd }}$ zone) the values of leaf sheaths thickness decrease. The leaf sheaths were covered with cuticle, the thickness of which increased along the transect towards the upper littoral. The cell size (length and width) of the upper and lower epidermis decreased from the $1^{\text {st }}$ to the $3^{\text {rd }}$ zone as the thickness of the sheaths do. In the upper epidermis, cell size was significantly different in three zones. The main part of the leaf sheaths was formed by aerenchyma, the cell volume of which increased from the $1^{\text {st }}$ zone to the $3^{\text {rd }}$ one by 1.3 times. The volume of intercellular spaces of aerenchyma also increased by almost 2.3 times. At the same time, a decrease in the vein diameter from the $1^{\text {st }}$ zone to the $3^{\text {rd }}$ one was recorded (Table 2).

The values of anatomical parameters of the rhizomes of $T$. maritima in the tidal zone decreased from the $1^{\text {st }}$ zone up to the $3^{\text {rd }}$ one (Table 3 ). The primary cortex formed the largest part of the rhizome with intercellular spaces. The rhizomes of T. maritima had well-developed mechanical tissue represented by sclereids. Two or three layers of sclereids were apparent in the primary cortex under the epidermis and separate cell groups were in the central cylinder of the rhizome. The volume of sclereids in the primary cortex was 2 times greater than in the central cylinder. The most significant decrease (by 1.5 times) in the values along the transect was found in the thickness of the sclereid layer and in the volume of the storage parenchyma cells in the primary cortex.

For adventitious roots, length and width of epibleme or rhizodermal cells (the covering tissue) cells in plants from the $1^{\text {st }}$ zone were 1.5 times greater than in plants from the $3^{\text {rd }}$ zone (Fig. 5). 
A. V. SONINA et al.

\begin{tabular}{|c|c|c|c|c|}
\hline \multirow{2}{*}{\multicolumn{2}{|c|}{ Parameters }} & \multicolumn{3}{|c|}{ Zone } \\
\hline & & 1 & 2 & 3 \\
\hline \multicolumn{2}{|c|}{ Leaf sheaths thickness, $\mu \mathrm{m}$} & $1503.0 \pm 7.4^{*}$ & $1400.6 \pm 9.2 *$ & $1300.0 \pm 8.1^{*}$ \\
\hline \multicolumn{2}{|c|}{ Cuticle thickness, $\mu \mathrm{m}$} & $6.7 \pm 0.2 *$ & $8.1 \pm 0.3^{*}$ & 12.7 $\pm 0.1 *$ \\
\hline \multirow{2}{*}{$\begin{array}{l}\text { Upper } \\
\text { epidermis }\end{array}$} & Cell length, $\mu \mathrm{m}$ & 44.6 $\pm 1.0^{*}$ & 39.0 $\pm 1.0 *$ & 37.0 $\pm 0.7^{*}$ \\
\hline & Cell width, $\mu \mathrm{m}$ & 31.2 $\pm 1.0^{*}$ & $28.6 \pm 0.7^{*}$ & $26.5 \pm 0.8^{*}$ \\
\hline \multirow{2}{*}{$\begin{array}{l}\text { Lower } \\
\text { epidermis }\end{array}$} & Cell length, $\mu \mathrm{m}$ & $37.4 \pm 1.1^{*}$ & $\mathbf{3 4 . 4} \pm 0.8$ & 33.5 \pm 0.4 \\
\hline & Cell width, $\mu \mathrm{m}$ & 24.1 $\pm 0.6^{*}$ & $\mathbf{2 2 . 3} \pm 0.6$ & $22.1 \pm 0.4$ \\
\hline \multicolumn{2}{|c|}{$\begin{array}{l}\text { Volume of aerenchyma cells, } \\
\text { thousand } \mu \mathrm{m}^{3}\end{array}$} & $\mathbf{1 6 2 . 5} \pm 15,8^{*}$ & $\mathbf{1 8 9 . 5} \pm 15.6$ & $215.2 \pm 12.4^{*}$ \\
\hline \multicolumn{2}{|c|}{$\begin{array}{l}\text { Volume of aerenchyma } \\
\text { intercellular spaces, } \\
\text { thousand } \mu \mathrm{m}^{3}\end{array}$} & 3 118.3 $\pm 201.4^{*}$ & $3887.2 \pm 160.7^{*}$ & $7032.8 \pm 265.5^{*}$ \\
\hline \multicolumn{2}{|c|}{ Vein diameter, $\mu \mathrm{m}$} & $96.3 \pm 1.3^{*}$ & $85.6 \pm 3.0^{*}$ & $76.6 \pm 2.0^{*}$ \\
\hline
\end{tabular}

Table 2. Anatomical parameters of leaf sheaths of Triglochin maritima.

Note: * differences in the parameters of plants from different zones of the transect are significant $(\mathrm{p}<0.05)$

\begin{tabular}{|c|c|c|c|}
\hline \multirow{2}{*}{\multicolumn{2}{|c|}{ Parameters }} & \multicolumn{2}{|c|}{ Zone } \\
\hline & & 1 & 2 \\
\hline \multirow{2}{*}{ Epidermis } & Cell length, $\mu \mathrm{m}$ & 26.1 $\pm 0.5^{*}$ & 23.1 \pm 0.6 \\
\hline & Cell width, $\mu \mathrm{m}$ & $18.1 \pm 0.5^{*}$ & $\mathbf{1 6 . 0} \pm 0.5$ \\
\hline \multicolumn{2}{|c|}{ Primary cortex thickness, $\mu \mathrm{m}$} & $1368.0 \pm 19.3^{*}$ & $1236.5 \pm 20.7$ \\
\hline \multicolumn{2}{|c|}{$\begin{array}{l}\text { Thickness of sclereid layer in primary } \\
\text { cortex, } \mu \mathrm{m}\end{array}$} & $113.5 \pm 3.4^{*}$ & $\mathbf{7 0 . 7} \pm 2.0$ \\
\hline \multirow{3}{*}{$\begin{array}{l}\text { Cell volume, } \\
\text { thousand } \mu \mathrm{m}^{3}\end{array}$} & $\begin{array}{l}\text { storage parenchyma in } \\
\text { the primary cortex }\end{array}$ & $9.7 \pm 0.3 *$ & $\mathbf{6 . 0} \pm 0.4$ \\
\hline & $\begin{array}{l}\text { sclereids in the } \\
\text { primary cortex }\end{array}$ & $6.3 \pm 0.5^{*}$ & $\mathbf{4 . 8} \pm 0.3$ \\
\hline & $\begin{array}{l}\text { sclereids in the central } \\
\text { cylinder }\end{array}$ & $3.2 \pm 0.3 *$ & $\mathbf{2 . 4} \pm 0.3$ \\
\hline \multicolumn{2}{|c|}{$\begin{array}{l}\text { Volume of intercellular spaces in } \\
\text { primary cortex, thousand } \mu \mathrm{m}^{3}\end{array}$} & $\mathbf{5 1 . 7} \pm 3.0^{*}$ & $40.6 \pm 3.0$ \\
\hline
\end{tabular}

Table 3. Parameters of the anatomical structure of rhizomes of Triglochin maritima.

Note: * differences in the parameters of plants from different zones of the transect are significant $(\mathrm{p}<0.05)$.

Exoderm cell sizes differed significantly among plants from three different zones. The mesoderm formed the main part of the root. Its cells were larger than other cortex cells. The size of the mesoderm cells was 2 times larger than the exoderm cells and 2.5-3 times larger than the endoderm cells. In the $1^{\text {st }}$ and $2^{\text {nd }}$ zone, there were no sig- nificant differences in the length and width of mesoderm cells, but they were 1.5 times smaller in the $3^{\text {rd }}$ zone. Starch grains were stored in this tissue. Intercellular spaces volume reached, $2480 \pm 318$ thousand $\mu \mathrm{m}^{3}$ ( $1^{\text {st }}$ zone $), 1880 \pm 214$ thousand $\mu \mathrm{m}^{3}\left(2^{\text {nd }}\right.$ zone), and $1400 \pm 158$ thousand $\mu \mathrm{m}^{3}\left(3^{\text {rd }}\right.$ zone). The thickness of the mesoderm 
decreased from $540 \pm 5 \mu \mathrm{m}$ (the $1^{\text {st }}$ zone) to $514 \pm 4 \mu \mathrm{m}$ (the $2^{\text {nd }}$ zone) and ended with $469 \pm 8 \mu \mathrm{m}$ (the $3^{\text {rd }}$ zone). Endoderm cells were the smallest among the cells of root tissues. In the $1^{\text {st }}$ zone, the length and width of endoderm cells significantly differ from the sizes of cells in the $2^{\text {nd }}$ and $3^{\text {rd }}$ zones, where no significant differences were found.
The thickness of leaf sheaths, size of the cells of the upper and lower epidermis, diameter of veins, anatomical parameters of rhizomes and adventitious roots decreased, while the thickness of the cuticle and the volume of aerenchyma cells and intercellular spaces in leaf sheaths increased along the transect from the lower to upper littoral.

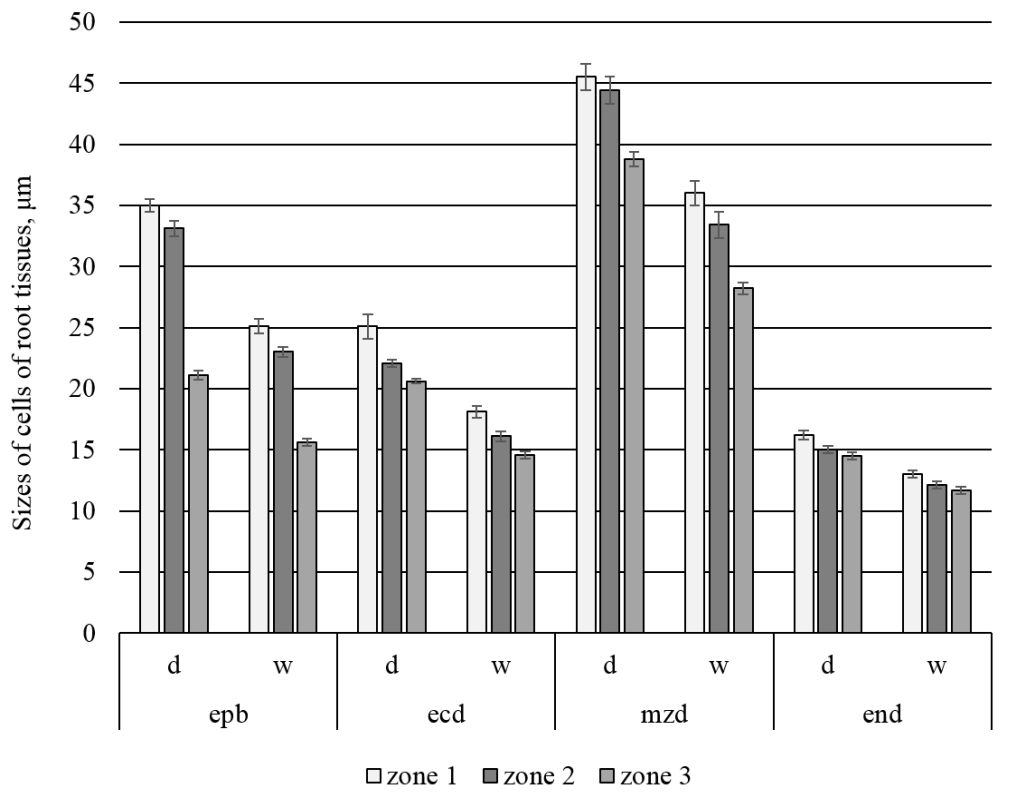

Fig. 5. Sizes of cells of root tissues of Triglochin maritima.

Note: epb - epibleme, ecd - exodermis, mzd - mesoderm, end - endoderm, d - cell length, $\mathrm{w}-$ cell width.

\section{Palynological analysis}

Palynological analysis showed that from 62 to $93 \%$ of $T$. maritima pollen grains corresponded to the norm described in the literature (Pires and Medeanis 2006, Halbritter 2016): they have a rounded or slightly elongated shape, a distinct reticularcolumnar structure of the exine, stained dark pink with acetocarmine. The cytoplasm of the vegetative cells was uniformly structured and stained, nuclei were visible; no aperture; zone of exine thinning for the emergence of a pollen tube was not visible. The CV values for normally formed pollen differed between the transect zones more than twice, but varied within 7\% (Table 4).

The most common observed defect in the pollen structure was lumpy, unevenly stained cytoplasm of the vegetative cell (1.5-10.0\%; CV 23-33\%). The second most common developmental defect was empty pollen grains $(0.2-1.7 \%$; CV $75-$ $100 \%$ ). Such pollen grains do not have cytoplasm and generative cells, and their 
membranes are almost unstained. Specific developmental defects of pollen were recorded for plants growing in the $2^{\text {nd }}$ and $3^{\text {rd }}$ zones. Pollen grains underwent destruction at the tetrad stage. They were without content and showed no response when stained with carmine (6.8-27.3\%; CV 12-76\%). This type of defects in development was observed almost four times more often in plants from the $3^{\text {rd }}$ zone than in the other ones. The quality of pollen from the plants of the $3^{\text {rd }}$ zone was weak. Normally developed pollen grains reached minimum relative share, while cytoplasmic structural defects and destructed tetrads reached maximum share. This was probably due to the fact that this part of the tidal zone was exposed to air (i.e. not flooded) during the longest periods.

\begin{tabular}{|c|c|c|c|c|c|c|c|}
\hline \multicolumn{2}{|c|}{$\begin{array}{c}\text { Pollen grain } \\
\text { morphology }\end{array}$} & norm & empty & $\begin{array}{c}\text { lumpy } \\
\text { cytoplasm }\end{array}$ & gigant & dwarf & tetrads \\
\hline \multirow{2}{*}{ Zone 1} & $\%$ & $\mathbf{9 1 . 9} \pm 2.3$ & $\mathbf{1 . 7} \pm 1.7$ & $\mathbf{5 . 7} \pm 1.3$ & $\mathbf{0 . 4} \pm 0.4$ & $\mathbf{0 . 3} \pm 0.2$ & $\mathbf{0}$ \\
\cline { 2 - 8 } & $\mathrm{CV}$ & 3 & 100 & 23 & 100 & 67 & 0 \\
\hline \multirow{2}{*}{ Zone 2} & $\%$ & $\mathbf{7 8 . 9} \pm 5.3$ & $\mathbf{1 . 6} \pm 1.2$ & $\mathbf{1 . 5} \pm 0.5$ & $\mathbf{1 . 0} \pm 0.7$ & $\mathbf{1 0 . 2} \pm 2.5$ & $\mathbf{6 . 8} \pm 5.2$ \\
\cline { 2 - 8 } & $\mathrm{CV}$ & 7 & 75 & 33 & 70 & 24 & 76 \\
\hline \multirow{2}{*}{ Zone 3} & $\%$ & $\mathbf{6 2 . 6} \pm 4.2$ & $\mathbf{0 . 2} \pm 0.2$ & $\mathbf{1 0 . 0} \pm 2.9$ & $\mathbf{0 . 1} \pm 0.2$ & $\mathbf{0}$ & $\mathbf{2 7 . 3} \pm 3.5$ \\
\cline { 2 - 8 } & $\mathrm{CV}$ & 7 & 100 & 29 & 200 & 0 & 13 \\
\hline
\end{tabular}

Table 4. Analysis of the morphological structure of T. maritima pollen grains.

Notes: norm - pollen grains of normal morphological structure; empty - pollen grains without content; lumpy cytoplasm - pollen grains with unevenly stained cytoplasm shrinking away from the cell wall; giant - pollen grains, the size of which exceed the norm by 1.5 or more times; dwarf - pollen grains, the size of which is 1.5 or more times less than normal; tetrads - undivided pollen grains without content.

\section{Content of elements in sea water and littoral soils}

Sea water in the area where T. maritima grows was contaminated with $\mathrm{Ni}$ (14.8 maximum permissible concentration - MPC) and $\mathrm{Pb}$ (2.4 MPC); the values for nitrates were close to MPC (0.9 MPC). The content of $\mathrm{Fe}, \mathrm{Mn}$ and $\mathrm{Zn}$ in water exceeded the background by factors of 4, 5.5 and 2.8 , correspondingly. The $\mathrm{Cu}$ content in sea water was low, not exceeding background values (Table 5).

The littoral soils were not contaminated with heavy metals. The contents of $\mathrm{Cu}, \mathrm{Zn}$, $\mathrm{Pb}$ and $\mathrm{Ni}$ did not exceed the values of the background content in the bottom sediments. Fe content reached $14000 \mathrm{mg} \mathrm{kg}^{-1}$ and $\mathrm{Mn}-71 \mathrm{mg} \mathrm{kg}^{-1}$. The content of macronutrients (N, P, K and $\mathrm{C}$ ) in the littoral soils was also low compared to gray forest soils (Table 5). The content of metals in soils increased from the $1^{\text {st }}$ to the $3^{\text {rd }}$ zone, on average by $1.5-2.5$ times (Table 5).

\section{The content of heavy metals in T. maritima plants}

Fe content in $T$. maritima plants (22$34 \mathrm{~g} \mathrm{~kg}^{-1}$ ) was significantly higher than the known critical level for $\mathrm{Fe}$ in plants. In T. maritima plants $\mathrm{Fe}$ was dominating accumulated metal. The content of other metals was much lower. Mn ranged 173$219 \mathrm{mg} \mathrm{kg}^{-1}, \mathrm{Cu}: 22-36 \mathrm{mg} \mathrm{kg}{ }^{-1}, \mathrm{Zn}: 36-$ $43 \mathrm{mg} \mathrm{kg}^{-1}, \mathrm{~Pb}: 16-24 \mathrm{mg} \mathrm{kg}^{-1}$ and $\mathrm{Ni}$ : 13-18 $\mathrm{mg} \mathrm{kg}^{-1}$. These values did not exceed the MPC values in plants. 


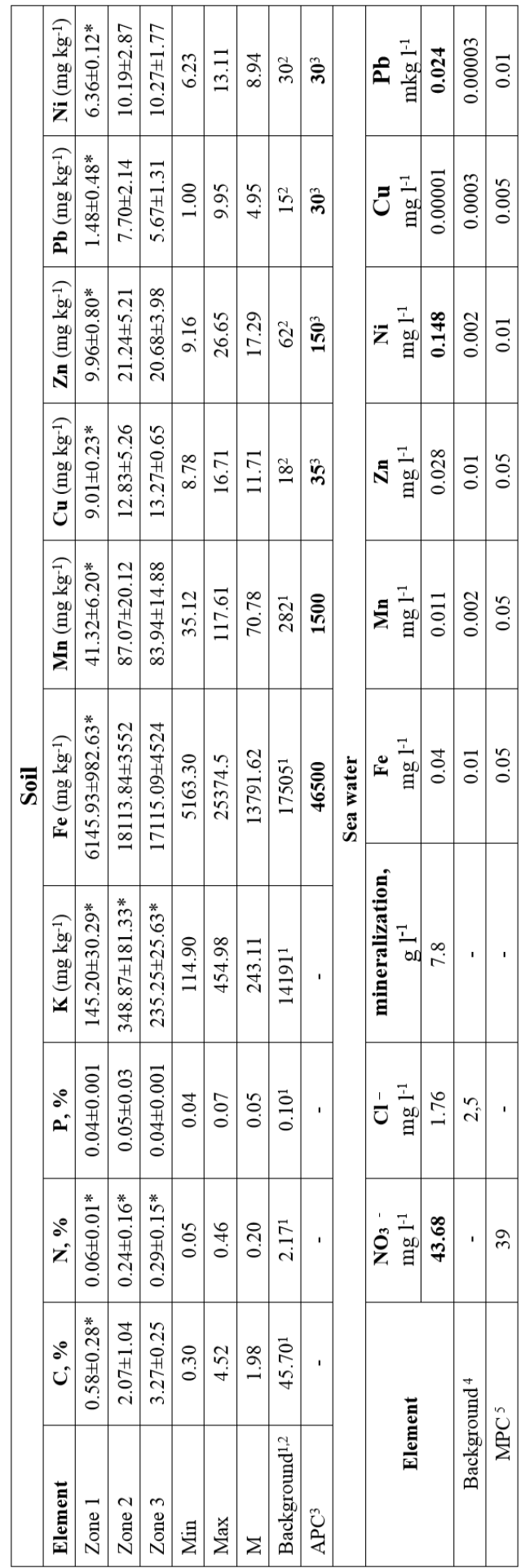

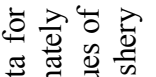

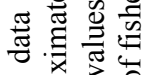

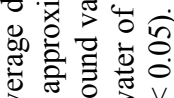

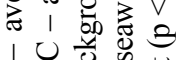

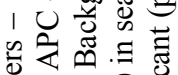

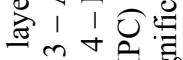

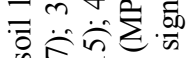

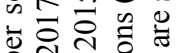

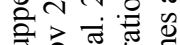

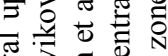

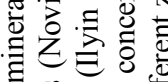

$\Xi$ छे 응

s $\bar{c}$

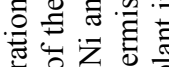

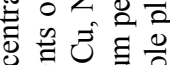

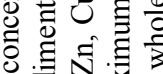

च

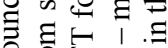

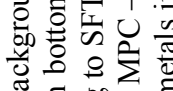

๑ $\Xi$ on

1 边

- 曹家节

ญ छ

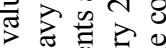

可焉

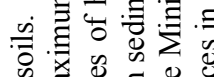

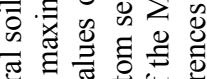

।

至

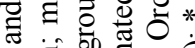

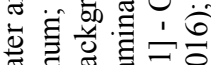

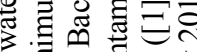

刃्

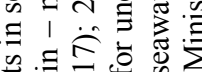

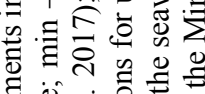

ฮี สं

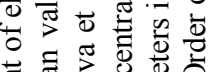

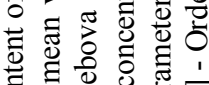

ठี

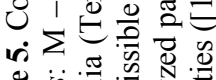

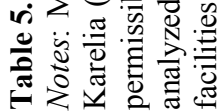


The total content of all investigated met- tent of all studied metals was $22-23 \mathrm{~g} \mathrm{~kg}^{-1}$ als was highest in the $1^{\text {st }}$ zone $-34 \mathrm{~g} \mathrm{~kg}^{-1}$. (Table 6). In the $2^{\text {nd }}$ and the $3^{\text {rd }}$ zones the total con-

\begin{tabular}{|c|c|c|c|c|c|c|c|}
\hline Element & $\begin{array}{c}\mathbf{F e} \\
\mathrm{mg} \mathrm{kg}^{-1}\end{array}$ & $\begin{array}{c}\text { Mn } \\
\mathrm{mg} \mathrm{kg}^{-1} \\
\end{array}$ & $\begin{array}{c}\mathbf{C u} \\
\mathrm{mg} \mathrm{kg}^{-1}\end{array}$ & $\begin{array}{c}\mathbf{Z n} \\
\mathrm{mg} \mathrm{kg}^{-1} \\
\end{array}$ & $\begin{array}{c}\mathbf{P b} \\
\mathrm{mg} \mathrm{kg}^{-1}\end{array}$ & $\begin{array}{c}\mathbf{N i} \\
\mathrm{mg} \mathrm{kg}^{-1}\end{array}$ & $\begin{array}{l}\text { TMC } \\
\mathrm{g} \mathrm{kg}^{-1}\end{array}$ \\
\hline \multicolumn{8}{|c|}{ Zone 1} \\
\hline $\mathrm{M}$ roots & $\begin{array}{c}29077.96 \\
\pm 55.25\end{array}$ & $\begin{array}{l}\mathbf{1 0 3 . 2 5} \\
\pm 21.24\end{array}$ & $\begin{array}{l}\mathbf{2 3 . 8 8} \\
\pm 4.52\end{array}$ & $\begin{array}{l}\mathbf{2 6 . 6 8} \\
\pm 2.89\end{array}$ & $\begin{array}{l}\mathbf{2 2 . 3 2} \\
\pm 2.85\end{array}$ & $\begin{array}{c}\mathbf{9 . 5 7} \\
\pm 1.58\end{array}$ & $\begin{array}{c}\mathbf{2 9} \\
\pm 1^{*}\end{array}$ \\
\hline $\begin{array}{l}\text { M aboveground } \\
\text { organs }\end{array}$ & $\begin{array}{l}\mathbf{4 8 8 3 . 9 9} \\
\pm 115.21\end{array}$ & $\begin{array}{c}\mathbf{7 7 . 8 4} \\
\pm 15.28\end{array}$ & $\begin{array}{c}\mathbf{4 . 1 1} \\
\pm 1.07\end{array}$ & $\begin{array}{c}\mathbf{8 . 9 9} \\
\pm 1.96\end{array}$ & $\begin{array}{c}\mathbf{2 . 0 8} \\
\pm 0.85\end{array}$ & $\begin{array}{c}\mathbf{3 . 6 7} \\
\pm 0.52\end{array}$ & $\begin{array}{c}\mathbf{5} \\
\pm 0.5\end{array}$ \\
\hline $\begin{array}{l}\text { M plant, } \\
\text { mg kg}^{-1}\end{array}$ & $\begin{array}{c}33961.94 \\
\pm 7.56^{*} \\
\end{array}$ & $\begin{array}{c}\mathbf{1 8 1 . 0 9} \\
\pm 15.29 *\end{array}$ & $\begin{array}{l}\mathbf{2 7 . 9 9} \\
\pm 3.25 \\
\end{array}$ & $\begin{array}{c}\mathbf{3 5 . 6 8} \\
\pm 2.89^{*}\end{array}$ & $\begin{array}{c}\mathbf{2 4 . 4 0} \\
\pm 3.25^{*}\end{array}$ & $\begin{array}{c}\mathbf{1 3 . 2 4} \\
\pm 3.36^{*}\end{array}$ & $\begin{array}{c}\mathbf{3 4} \\
\pm 3^{*} \\
\end{array}$ \\
\hline CBA roots & 4.73 & 2.50 & 2.65 & 2.67 & 15.11 & 1.47 & \\
\hline $\begin{array}{l}\text { CBA aboveground } \\
\text { organs }\end{array}$ & 0.79 & 1.88 & 0.46 & 0.90 & 1.41 & 0.56 & \\
\hline CBA whole plant & 5.53 & 4.38 & 3.11 & 3.57 & 16.53 & 2.04 & \\
\hline \multicolumn{8}{|c|}{ Zone 2} \\
\hline $\mathrm{M}$ roots & $\begin{array}{c}\mathbf{1 8 5 3 8 . 9 8} \\
\pm 201.63\end{array}$ & $\begin{array}{l}\mathbf{1 4 2 . 5 4} \\
\pm 15.65\end{array}$ & $\begin{array}{l}\mathbf{1 7 . 3 6} \\
\pm 3.58\end{array}$ & $\begin{array}{l}\mathbf{3 3 . 9 4} \\
\pm 2.45\end{array}$ & $\begin{array}{l}\mathbf{1 5 . 1 2} \\
\pm 1.52\end{array}$ & $\begin{array}{l}\mathbf{1 4 . 9 8} \\
\pm 2.87\end{array}$ & $\begin{array}{l}\mathbf{1 9} \\
\pm 2\end{array}$ \\
\hline $\begin{array}{l}\text { M aboveground } \\
\text { organs }\end{array}$ & $\begin{array}{l}\mathbf{3 9 5 5 . 8 2} \\
\pm 325.00 \\
\end{array}$ & $\begin{array}{l}\mathbf{7 6 . 5 8} \\
\pm 8.96 \\
\end{array}$ & $\begin{array}{c}\mathbf{4 . 4 3} \\
\pm 1.00 \\
\end{array}$ & $\begin{array}{r}\mathbf{9 . 5 6} \\
\pm 1.69 \\
\end{array}$ & $\begin{array}{c}\mathbf{1 . 7 0} \\
\pm 0.78 \\
\end{array}$ & $\begin{array}{c}\mathbf{3 . 4 2} \\
\pm 1.20 \\
\end{array}$ & $\begin{array}{c}\mathbf{4} \\
\pm 0.2 \\
\end{array}$ \\
\hline M plant, $\mathrm{mg} \mathrm{kg}^{-1}$ & $\begin{array}{c}22 \mathbf{4 9 4 . 8 0} \\
\pm 154.25 \\
\end{array}$ & $\begin{array}{c}\mathbf{2 1 9 . 1 2} \\
\pm 10.23 * \\
\end{array}$ & $\begin{array}{l}\mathbf{2 1 . 7 9} \\
\pm 4.85 \\
\end{array}$ & $\begin{array}{l}\mathbf{4 3 . 5 0} \\
\pm 5.85 \\
\end{array}$ & $\begin{array}{l}\mathbf{1 6 . 8 2} \\
\pm 3.87 \\
\end{array}$ & $\begin{array}{l}\mathbf{1 8 . 4 0} \\
\pm 1.85 \\
\end{array}$ & $\begin{array}{l}\mathbf{2 3} \\
\pm 2 \\
\end{array}$ \\
\hline CBA roots & 1.02 & 1.64 & 1.35 & 1.60 & 1.96 & 1.45 & \\
\hline $\begin{array}{l}\text { CBA aboveground } \\
\text { organs }\end{array}$ & 0.22 & 0.88 & 0.35 & 0.45 & 0.22 & 0.33 & \\
\hline CBA whole plant & 1.24 & 2.52 & 1.70 & 2.05 & 2.18 & 1.78 & \\
\hline \multicolumn{8}{|c|}{ Zone 3} \\
\hline $\mathrm{M}$ roots & $\begin{array}{c}\mathbf{2 0 ~ 5 8 0 . 6 4} \\
\pm 252.23 \\
\end{array}$ & $\begin{array}{l}\mathbf{1 4 7 . 1 9} \\
\pm 25.63 \\
\end{array}$ & $\begin{array}{l}\mathbf{3 1 . 3 4} \\
\pm 5.85\end{array}$ & $\begin{array}{l}\mathbf{3 3 . 6 2} \\
\pm 2.96 \\
\end{array}$ & $\begin{array}{l}\mathbf{1 7 . 5 1} \\
\pm 2.54 \\
\end{array}$ & $\begin{array}{l}\mathbf{1 4 . 5 3} \\
\pm 3.69 \\
\end{array}$ & $\begin{array}{l}\mathbf{2 0} \\
\pm 3\end{array}$ \\
\hline $\begin{array}{l}\text { M aboveground } \\
\text { organs }\end{array}$ & $\begin{array}{c}1 \mathbf{5 2 6 . 8 3} \\
\pm 25.87 \\
\end{array}$ & $\begin{array}{l}\mathbf{2 6 . 3 7} \\
\pm 9.00 \\
\end{array}$ & $\begin{array}{r}4.99 \\
\pm 0.52 \\
\end{array}$ & $\begin{array}{c}\mathbf{7 . 2 3} \\
\pm 1.24 \\
\end{array}$ & $\begin{array}{r}\mathbf{1 . 1 7} \\
\pm 0.23 \\
\end{array}$ & $\begin{array}{r}\mathbf{1 . 5 4} \\
\pm 0.05 \\
\end{array}$ & $\begin{array}{c}\mathbf{2} \\
\pm 0.9 \\
\end{array}$ \\
\hline M plant, $\mathrm{mg} \mathrm{kg}^{-1}$ & $\begin{array}{c}22 \mathbf{1 0 7 . 4 7} \\
\pm 127.00 \\
\end{array}$ & $\begin{array}{l}\mathbf{1 7 3 . 5 6} \\
\pm 8.23 \\
\end{array}$ & $\begin{array}{c}\mathbf{3 6 . 3 3} \\
\pm 1.89^{*} \\
\end{array}$ & $\begin{array}{l}\mathbf{4 0 . 8 5} \\
\pm 5.12 \\
\end{array}$ & $\begin{array}{l}\mathbf{1 8 . 6 9} \\
\pm 4.21 \\
\end{array}$ & $\begin{array}{l}\mathbf{1 6 . 0 7} \\
\pm 5.78 \\
\end{array}$ & $\begin{array}{l}\mathbf{2 2} \\
\pm 3 \\
\end{array}$ \\
\hline CBA roots & 1.20 & 1.75 & 2.36 & 1.62 & 3.09 & 1.39 & \\
\hline $\begin{array}{l}\text { CBA aboveground } \\
\text { organs }\end{array}$ & 0.09 & 0.31 & 0.38 & 0.35 & 0.21 & 0.15 & \\
\hline CBA whole plant & 1.29 & 2.07 & 2.74 & 1.97 & 3.29 & 1.54 & \\
\hline $\begin{array}{l}\text { Critical level of } \\
\text { element in plants } \\
\mathrm{mg} \mathrm{kg}^{-1}\end{array}$ & $>500$ & $300-500$ & $20-100$ & $>100$ & $20-300$ & $10-100$ & \\
\hline
\end{tabular}

Table 6. The average values of the element contents $(\mathrm{M})$ and the coefficient of biological absorption (CBA) of metals by adventitious roots, aboveground organs and whole plant of Triglochin maritima in different zones along the flooding gradient. Notes: TMC - Total metal content. *Critical level of element in plants, $\mathrm{mg} \mathrm{kg}^{-1}$ (Pendias 2010); *differences in the content of metals in the whole plant in different zones are significant $(\mathrm{p}<0.05)$. 
T. maritima plants accumulated metals by the whole plant $(\mathrm{CBA}>1)$. However, roots accumulated metals more intensely than aboveground organs (Table 6). Metal accumulation by the whole plant followed the order: $\mathrm{Pb}(7.33)>\mathrm{Mn}(2.99)>\mathrm{Fe}$

\section{Discussion}

T. maritima dominated vegetation cover of the littoral zone within the studied transect. It has an important role in stabilization of initial communities (Sergienko 2008) In the present study, a complex of biological and environmental parameters was analyzed, which allowed to identify some adaptive features of $T$. maritima to specific environmental conditions. It was found that $T$. maritima plants successfully grown within the entire transect, where conditions differed due to tidal dynamics. In the $1^{\text {st }}$ zone, plants have adapted by decreasing vegetative aboveground biomass, number of ramets in a clone and increasing adventitious root length (Table 1). Such adaptations may provide them stronger anchoring than in other two zones. This corresponds with increased length and width of root cells. Consequently, thickness of roots of plants in the $1^{\text {st }}$ zone was significantly greater than in plants in the $3^{\text {rd }}$ zone. A similar change in tissue cell size was found in rhizomes. The mechanical tissue of sclerenchyma was well developed in rhizomes, which also aimed at the sustainable existence of $T$. maritima plants under unstable conditions. Intensive formation of mechanical tissues in the aboveground and underground vegetative organs of different types of halophytes was also reported in other works (Nagalevsky 2001). The presence of sclerenchyma in rhizomes contributes to the retention of $T$. maritima plants under conditions of tidal dynamics, especially in the $1^{\text {st }}$ zone, where the greatest thickness of the sclereid layer in the primary cortex was determined.
(2.69) $>\mathrm{Zn}(2.53)>\mathrm{Cu}(2.51)>\mathrm{Ni}(1.79)$. The CBA for $\mathrm{Pb}$ was very high (Table 6). Plants from the $1^{\text {st }}$ zone had the maximum CBA of metals, compared to the plants in the $2^{\text {nd }}$ and $3^{\text {rd }}$ zones (Table 6 ).

In the aboveground organs at the water edge (in the $1^{\text {st }}$ zone), thickening of leaf sheaths was revealed, while the cuticular layer was reduced. Similar data were obtained for leaves of T. maritima in the tidal zone of the White Sea (Morozova and Anisimova 2015). Thin cuticules were also observed in other halophytes (Nagalevsky 2001, Markovskaya and Gulyaeva 2020). This might be associated with the regulation of transpiration since the plants growing in the lower littoral do not save water in contrast to plants in the upper littoral (i.e. not flooded and exposed to air for longer periods. Volumes of aerenchyma cells and intercellular spaces also increase towards the upper littoral in leaves (Morozova and Anisimova 2015) and their sheaths, which indicates an increase in oxygen and carbon dioxide supply in plants from the $3^{\text {rd }}$ zone with irregular water supply and high illumination.

Anatomical features of T. maritima vegetative organs are consistent with the data on the accumulation and distribution of metals in the tissues and organs of plants depending on the habitat state. In the lower littoral zone plant had more developed protective tissues (epiblema, exoderm, mesoderm, endoderm) in adventitious roots (Table 3, Fig. 5) and higher concentrations of accumulated metals (especially $\mathrm{Fe}$ in the roots) compared to the plants in the upper littoral zone (Table 6). According to their role in metal metabolism, root tissues can be divided into five groups: (1) absorbers responsible for the absorption of heavy metals from the environment (epiblema with 
rhizodermal transfer cells); (2) tissues performing barrier function, which limit the radial transport of metals in the roots (endoderm); (3) metal accumulators (exoderm, mesoderm); (4) collectors that ensure the redistribution of ions along the perimeter of the central cylinder and their entry into conducting system (pericycle); (5) interorgan transporters that participate in the long-distance transport of metals through the plant (xylem, phloem) (Seregin and Kozhevnikova 2008). Consequently, the more developed the primary root bark, the more metal ions can be absorbed and accumulated in plant roots. Due to the root accumulation of heavy metals, plant roots along with bacteria and fungi, are used in wastewater phytoremediation (Choubey and Godbole 2021). High adsorption capacity of roots of freshwater plants (Eichhornia crassipes (Mart.) Solms, Tripha latifolia L., Sparganium minimum Wallr. and Menyanthes trifoliata L.) to absorb copper, lead, uranium and mercury ions from aqueous solution was established (Zheng et al. 2016, Robichaud et al. 2021).

In general, the littoral soil in the study area was not contaminated, but increased concentrations of some elements were revealed in water, for example, $\mathrm{Ni}$ concentration was $0.148 \mathrm{mg} \mathrm{l}^{-1}, \mathrm{~Pb}-0.024 \mathrm{mg} \mathrm{l}^{-1}$ (Table 5). Thus, water was contaminated with Ni (14.8 MPC), Pb (2.4 MPC) and nitrates (0.9 MPC). According Ilyin et al. (2015), the input of nutrients and pollutants in the White Sea occurs with the runoffs of large rivers (the Onega, Severnaya Dvina, Kem, Nizhniy Vyg, Verkhniy Vyg, Keret). The volume of wastewater discharged into surface water bodies of the White Sea basin in the year of 2019 amounted to 73.87 million $\mathrm{m}^{3}$ (in 2018 70.13 million $\mathrm{m}^{3}$ ), including 14.98 million $\mathrm{m}^{3}$ of wastewater from the tailing dump of joint stock company Karelsky Okatysh. The main pollutants in the water of the Karelsky Okatysh tailing dump are $\mathrm{Ni}$ (0.017-0.025 mg l $\left.{ }^{-1}\right)$, Mn (0.432-0.650 $\left.\mathrm{mg}^{-1}\right)$ and $\mathrm{Zn}\left(0.05-0.075 \mathrm{mg} \mathrm{l}^{-1}\right)$, and in the technogenic substrate of the plant is $\mathrm{Fe}$ (39 505- $45120 \mathrm{mg} \mathrm{kg}^{-1}$ ) (Terebova et al. 2017). Among pollutants discharged into the water bodies of the White Sea basin in 2019 , the largest contribution by mass was made by sulphate lignin (3014.88 tons), K (1982.43 tons), nitrates (1446.41 tons), Mn (601.51 tons), Na (524.35 tons), Fe (30.51 tons), oil products (11.92 tons), and $\mathrm{Ni}$ $(898.64 \mathrm{~kg})([2]-$ State report 2020).

In addition to the technogenic influx of heavy metals from river runoffs into the waters of the White Sea, geologists associate the high level of iron with natural factors. These are the features of the White Sea drainage basin such as the widespread swamps and the inflows of groundwater into rivers. For example, the iron content in waters of the mouth area of the Northern Dvina was 0.289-0.453 $\mathrm{mg} \mathrm{l}^{-1}$ (20152019). This is five times higher than the background concentration of $\mathrm{Fe}(0.066$ $\mathrm{mg} \mathrm{l}^{-1}$ ) in the rivers of the world (Gordeev et al. 2021, Dzhamalov et al. 2019).

T. maritima plants actively absorb heavy metals from the environment, as evidenced by the value of CBA $>1$ (Table 6). However, there are some differences between the zones along the transect. Thus, the content of analyzed elements in the soil from the $1^{\text {st }}$ zone is less than from the $3^{\text {rd }}$ zone (Table 5), while their content in plants is higher in the $1^{\text {st }}$ zone. It might be that in the $1^{\text {st }}$ zone $T$. maritima plants have no competitors for the absorption of mineral substances from the soil as in the $1^{\text {st }}$ zone (a) vegetation cover is sparse and (b) $T$. maritima plants grow as separate medium-sized clones. In the upper littoral (in the $3^{\text {rd }}$ zone), where the vegetation cover is sufficiently developed covering $100 \%$ of surface area, the competition for mineral substances increases and T. maritima plants accumulate less mineral elements even at their higher content in the soil.

There are no data on the accumulation of elements in plants under conditions of lower, middle and upper littoral zones. It is known that the content of calcium, magne- 
sium, potassium and sodium in the bottom sediments of the Kandalaksha Bay of the White Sea decreases from the lower littoral to the coast soils and the content of organic carbon, on the contrary, increases in the same direction (Sidorova et al. 2015). Our studies carried out within the littoral zone only have shown that the content of all elements (organic carbon, nitrogen, phosphorus and iron) decreases from the lower littoral (the $1^{\text {st }}$ zone) to the upper littoral (the $3^{\text {rd }}$ zone).

In all three zones among plant organs, adventitious roots accumulate more minerals (Table 6). It is consistent with the data of anatomical analysis, which indicate an increase in the size of root cells and all root tissues (Fig. 5), as well as an increase in the morphological parameters of shoots (Fig. 4), which indirectly reflects plant vigor. It is well known that the root system and its tissues are the first plant barrier against pollutants (Van Osten and Maggio 2015). Plant adaptation is aimed to immobilize contaminants in roots in order to protect reproductive organs and seeds from their toxic effects (Yadav 2010, Naila et al. 2019). It should be noted that T. maritima is a rhizome plant that accumulates metals in the underground organs throughout the life of the plant, while the aboveground part of the plants dies off every year and its mineral elements feed the littoral and coast soils.

Halophytes ordinarily have high tolerance to heavy metals compared with glycophytes (Manousaki and Kalogerakis 2011). The high resistance of halophytes to heavy metals is strongly connected to their salt tolerance characteristics (Wang et al. 2013). In general, plants respond to heavy metal toxicity via several molecular mechanisms. These include metal ions binding to cell wall, metals chelating within cytosol, ROS defense mechanisms (Bose et al 2014), and metal sequestration in vacuoles (Gargouri et al. 2013, Kushwaha et al. 2016). The cell wall is an important site for metal storage in plants as it provides a large number of metal-binding sites (Krzeslowska 2011). The cell wall is rich in carboxyl groups and plays a key role in the immobilization of metal ions, which alleviates metal toxicity to plant cells (Terebova et. al. 2020). The toxic effects of metal ions in cytosol can be eliminated by specific high affinity ligands, such as phytochelatins (PCs) (Zhang et al. 2010), soluble protein (Luo et al. 2011) and prolin (Wali et al. 2016, Liang et al. 2017). Therefore, the halophyte Suaeda salsa (L.) Pall. can grow in heavy metal-polluted areas along intertidal zones having high salinity. Since phytochelatins can effectively chelate heavy metals, it was hypothesized that $S$. salsa possessed a phytochelatin synthase (PCS) gene. The Suaeda salsa PCS transcript was more expressed in elongated and fibered roots and stems than in leaves. Lead and mercury exposure significantly enhanced the mRNA expression of Suaeda salsa PCS (Cong et al. 2016). In addition, Sesuvium portulacastrum (L.) L., a facultative halophyte, is known to induce the synthesis of PCs, specific metal(loid) binding ligands, in the presence of $\mathrm{Pb}$ (Zaier et al. 2010). $\mathrm{Cd}$ and $\mathrm{Cu}$ toxicity in the sea grass, Zostera marina L., was reported to be mitigated via the $\mathrm{PC}$-dependent detoxification pathway. Interestingly, it was observed that a PC gene was upregulated under high concentrations of $\mathrm{Cd}$ and $\mathrm{Cu}$ and low concentration of $\mathrm{Cu}$. This showed a HM-specific response of the $\mathrm{PC}$ gene in Z. marina (Greco et al. 2019).

According to the results of this study, T. maritima can be considered as a hyperaccumulator of Fe since the plant accumulates very high levels of Fe $\left(22-34 \mathrm{~g} \mathrm{~kg}^{-1}\right)$ (Naila et al. 2019), especially in the $1^{\text {st }}$ and $2^{\text {nd }}$ zones, both in underground and aboveground organs (Table 6). Fe content in the T. maritima tissues was thousands times higher than the content of other elements and five times higher than $\mathrm{Fe}$ content in the halophyte habitat (CBA for Fe: $1.29-$ 5.53). 
We have previously shown that the plants Plantago maritima L. and T. maritima inhabiting the littoral zone of the White Sea near the village of Keret also accumulate Fe up to levels of $13-22 \mathrm{~g} \mathrm{~kg}^{-1}$, respectively (Terebova et al. 2020). It is known that halophytes (Salicornia europaea L., Suaeda maritima (L.) Dumort, Salsola soda L. and Halimione portulacoides (L.) Aellen) from inland and maritime saline areas can accumulate up to 2.3 $\mathrm{g} \mathrm{kg}^{-1} \mathrm{Fe}$ in the whole plant and $1.3 \mathrm{~g} \mathrm{~kg}^{-1}$ in the roots (Milić et al. 2012). Heavy metals can bind to plant cell wall components (Pelloux et al. 2007, Richter et al. 2017). It is possible that the binding of $\mathrm{Fe}$ atoms by the cell wall of $T$. maritima roots and leaves can increase its rigidity, providing an increase in the plant organ strength under the conditions of the greatest dynamics of the sea.

According to the results of pollen analysis, indicating the level of plant wellbeing in specific habitat conditions, it can be concluded that in the $1^{\text {st }}$ zone, in the lower littoral, $T$. maritima plants grow under more favourable conditions. In this zone plants have the least percentage of teratomorphic pollen $(92 \%$ of normally formed pollen) with the lowest CV (2\%). In the $3^{\text {rd }}$ zone, the percentage of normal pollen has decreased to $63 \%(\mathrm{CV}=7 \%)$. The higher amount of teratomorphic pol-

\section{Conclusion}

The study of the ecological and biological features of T. maritima, which ensure the successful distribution of the dominant species within ecotopes with different conditions in the littoral of the White Sea, is of great scientific interest.

An integrated approach, including measurements of a number of parameters, allows concluding that in the littoral zone along the flooding gradient from the water edge to the supralittoral, the plants of this species are quite well adapted to the dy- len than $11 \%$ is considered as an indicator of unfavourable environmental conditions. For the first time, specific types of developmental disorders (undivided tetrads with pollen grains without content) were found in pollen samples from the $2^{\text {nd }}$ and $3^{\text {rd }}$ transect zones. Their number in the $3^{\text {rd }}$ zone reached $27.4 \%$. Thus, it can be concluded that habitat conditions for T. maritima in the $2^{\text {nd }}$ and $3^{\text {rd }}$ zones were stressful, affecting negatively pollen grain development. The $3^{\text {rd }}$ zone is characterized by the longest periods when plants are exposed to air, and in the $2^{\text {nd }}$ zone plans are affected by the most aggressive effect of the tidal cycle.

The morphological structure of T. maritima pollen grains indicate plant adaptation to wind pollination, i.e. pollen grains are small and smooth, and the absence of a pore for the exit of the pollen tube makes them less vulnerable to the influence of the aquatic environment. T. maritima flowers are protogynous, therefore, for the sexual process the transfer of pollen from another flower or plant is necessary. It is possible that much larger amount of normally formed, and therefore potentially fertile, pollen in plants in the $1^{\text {st }}$ zone facilitates the sexual reproduction of $T$. maritima under conditions of a short waterless period during low tide in this part of the littoral zone.

namic conditions. Adaptation to wave and storm impact is manifested in a well-developed system of underground vegetative organs. In the lower littoral (in the $1^{\text {st }}$ zone), underground part surpasses the aboveground vegetative organs in terms of the mass and the formation of mechanical tissues. This allows the plants to anchor stronger in the substrate. Pollen analysis confirmed the adaptability of T. maritima plants to the conditions of the lower littoral by a high percentage of normal and, 
consequently, fertile pollen, which ensures sexual reproduction of the species.

The ability of $T$. maritima plants to accumulate metals, revealed on the basis of the coefficient of biological absorption of metals, makes it possible to suggest potential utilization of the species in phytoremediation technologies on coastal territories.

Despite the fact that $T$. maritima has recently attracted the attention of scientists, for the restoration of transformed coastal territories, in particular, our study raises new questions in connection with the revealed ability of the species to hyperaccumulate Fe. The capacity of T. maritima to accumulate $\mathrm{Fe}$ and other metals should be addressed in follow-up studies. Another task is to evaluate adaptive characteristics that allow the species to grow under unstable biotope conditions.

\section{References}

Batalov, A. A., Giniyatullin, R. Kh. and Kagarmanov, I. R. (1991): Salicaceae - their participation in the formation of vegetation cover in technogenic landscapes of the Southern Urals. In: Proceedings of the conference «Flora and vegetation of Siberia and the Far East» dedicated to memory of L.M.Cherepnin. Krasnoyarsk, pp. 73-74. (In Russian).

Bobrov, Yu. A. (2018): Life forms of Triglochin maritima L. and Triglochin palustris L. in the north of European Russia. Bulletin of the Tverskoy State University. Ser. Biology and Ecology, 2: 139-146. (In Russian).

Borzenkova, R. A., Khramtsova, E. V. (2006): Determination of mesostructural characteristics of the photosynthetic apparatus of plants. Publishing house of the Ural University, Yekaterinburg, 26 p. (In Russian).

Bose, J., Rodrigo-Moreno, A. and Shabala, S. (2014): ROS homeostasis in halophytes in the context of salinity stress tolerance. Journal of Experimental Botany, 65 (5): 1241-1257. doi: $10.1093 / \mathrm{jxb} / \mathrm{ert} 430$

Buffington, K., Goodman, A.C., Freeman, C. and Thorne K.M. (2020): Testing the interactive effects of flooding and salinity on tidal marsh plant productivity. Aquatic Botany, 164 (9): 103231. doi: 10.1016/j.aquabot.2020.103231

Buzgo, M., Douglas, E., Soltis, D. E., Soltis, P. S., Kim, S., Ma, H., Hauser, B. A., LebensMack, J. and Johansen, B. (2006): Perianth Development in the Basal Monocot Triglochin maritima (Juncaginaceae). A Journal of Systematic and Evolutionary Botany, 22 (1): 107-125. doi: 10.5642/aliso.20062201.09

Choubey, S., Godboles, S. (2021): A review on bio sorption - an environment friendly method for removal of heavy metals from industrial wastes. International Journal of Recent Scientific Research Research, 12 (03): 41191-41197. doi: 10.24327/IJRSR

Cong, M., ZhaO, J., LÜ, J., ReN, Z. and Wu, H. (2016): Homologous cloning, characterization and expression of a new halophyte phytochelatin synthase gene in Suaeda salsa. Chinese Journal of Oceanology and Limnology, 34 (5) : 1034-1043. doi: 10.1007/s00343-016-4382-0

DAVY, A. J., BishoP, G. F. (1991): Triglochin maritima L. Journal of Ecology, 79 (2): 531-555.

Dzhamalov, R. G., Mironenko, A. A., Myagkova, K. G., Reshetnyak, O. S. and Safronova, T. I. (2019): Space-Time Analysis of the Hydrochemical Composition and Pollution of Water in the Northern Dvina Basin. Water Resources, 46 (2): 149-160. doi: 10.1134/S009780781902 0040

Edge, R. S., Sullivan, Mjp., Pedley, S. M. and Mossman, H. L. (2020): Species interactions modulate the response of saltmarsh plants to flooding. Annals of Botany, 125 (2): 315-324. doi: 10.1093/aob/mcz120

Gargouri, M., Magne, C., Dauvergne, X., Ksouri, R., El Feki, A., Metges, M.-A. G. and TAlarmin, H. (2013): Cytoprotective and antioxidant effects of the edible halophyte Sarcocornia perennis L. (swampfire) against lead-induced toxicity in renal cells. Ecotoxicology and Environmental Safety, 95: 44-51. 
Gordeev, V. V., Shevchenko, V. P., Korobov, V. B., Kochenkova, A. I., Starodymova, D. P., Belorukov, S. K., Lokhov, A. S., Yakovlev, A. E., Chultsova, A. L., Zolotyh, E. O. and LoBkovsky, L. I. (2021): Concertation and chemical elements in the water and suspended matter of the Severnaya Dvina River and their annual gross runoff into the White Sea. Doklady Earth Sciences, 500 (1): 95-102. doi: 10.1134/S1028334X21090099

Greco, M., Saez, C. A., Conteras, R. A., Rodriguez-Rojas, F., Bitonti, M. B. and Brown, M. T. (2019): Cadmium and/or copper excess induce interdependent metal accumulation, DNA methylation, induction of metal chelators and antioxidant defences in the seagrass Zostera marina. Chemosphere, 224: 11-119. doi: 10.1016/j.chemosphere.2019.02.123

Ilyin, G. V., Usygina, I. S. and Kasatkina, N. E. (2015): Geoecological state of seas in the environment in the Russian Arctic under the present technogenic stresses. Bulletin of the Kola Science Center of the Russian Academy of Sciences, 21: 82-93. (In Russian).

HAlBritTer, H. (2016): Triglochin maritima. B: PalDat - Palynological database. https://www. paldat.org/pub/Triglochin_maritima/302660;jsessionid=4ED626B384C11AB5C6E6E40078F4 945A; access 2020-07-04

KRZESŁOWSKA, M. (2011): The cell wall in plant cell response to trace metals: polysaccharide remodeling and its role in defense strategy. Acta Physiologiae Plantarum, 33: 35-51. doi: 10.1007/s11738-010-0581-z

Kushwaha, A., Rani, R., Kumar, S. and Gautam, A. (2016): Heavy metal detoxification and tolerance mechanisms in plants: Implications for phytoremediation. Environmental Reviews, 24(1): 39-51. doi: 10.1139/er-2015-0010

Liang, L., Liu, W., Huo X., Li, S. and Zhou, Q. (2017): Phytoremediation of Heavy MetalContaminated Saline Soils Using Halophytes: Current Progress and Future Perspectives Environmental Reviews, 25: 269-281. doi: 10.1139/er-2016-0063

Luo, H., Li, H., Zhang, X. and Fu, J. (2011): Antioxidant responses and gene expression in perennial ryegrass (Lolium perenne L.) under cadmium stress. Ecotoxicology, 20(4): 770-778. doi: 10.1007/s10646-011-0628-y

MANOUSAKI, E., KALOGERAKIS, N. (2011): Halophytes-An emerging trend in phytoremediation. International Journal of Phytoremediation, 13(10): 959-969. doi: 10.1080/15226514.2010. 532241

Markovskaya, E. F., Gulyaeva, E. N. (2020): Role of stomata in adaptation of Plantago maritima L. plants to tidal dynamics on the White Sea coast. Russian Journal of Plant Physiology, 67 (1): 75-83. doi: 10.1134/S1021443719060086

Milić, D., Luković, J., Ninkov, J., Zeremski-ŠKorić, T., Zorić, L., Vasin, J. and Milić, S. (2012): Heavy metal content in halophytic plants from inland and maritime saline areas. Central European Journal of Biology, 7(2): 307-317. doi: 10.2478/s11535-012-0015-6

Minin, E. M. (2014): Current state and development prospects of the Arctic region of Russia. Bulletin of the Moscow State Linguistic University, 23(709): 103. (In Russian).

Mokronosov, A. T., Borzenkova, R. A. (1978): Methods for the quantitative assessment of the structure of the functional activity of photosynthetic tissues and organs. Works on Applied Botany, Genetics and Breeding, 61(3): 119-133. (In Russian).

Morozova, K. V., Anisimova, D. I. (2015): Anatomical and morphological characteristics of the leaves of Triglochin maritima L. in coastal communities on the Pomor coast of the White Sea (Karelia). Problems of Modern Science and Education, 7(37): 40-44. (In Russian).

Nagalevsky, V. YA. (2001): Halophytes of the North Caucasus. Publishing house of the Kuban State University, Krasnodar, 246 p. (In Russian).

Naila, A., Meerdink, G., Jayasena, V., Sulaiman, A.Z., Ajit, A.B. and Graziella Berta, G. (2019): A review on global metal accumulators-mechanism, enhancement, commercial application, and research trend. Environmental Science and Pollution Research, 26: 2644926471. doi: 10.1007/s11356-019-05992-4

NoviKov, M. A. (2017): On the background values of heavy metal content in bottom sediments of the Barents Sea. Bulletin of the Murmansk State Technical University, 20(1/2): 280-288. (In Russian). doi: 10.21443/1560-9278-2017-20-1/2-280-288 
Pausheva, Z. P. (1980): Workshop on plant cytology. Agropromizdat, Moscow, 304 p. (In Russian).

PendiAs, A. (2010): Trace Elements in Soils and Plants. $4^{\text {th }}$ edition. Boca Raton, FL, USA: CRC Press/Taylor \& Francis Group, 548 p. doi: 10.1017/S0014479711000743

Pelloux, J., Rusterucci, C. and Mellerowicz, E. J. (2007): New insights into pectin methylesterase structure and function. Trends Plant Science, 12: 267-277. doi: 10.1016/j.tplants.2007. 04.001

Pires, E. F, Medeanic, S. (2006): Palynological implications of the preference of Triglochin in Holocene palaeoenvironmental reconstructions in the Coastal plain of Rio Grande do sul state, Brazil. Revista Española de Micropaleontología, 38(1): 93-101.

Polynov, B. B. (1956): Essay on the development of soil theory as a branch of natural science. Moscow, pp. 659-726. (In Russian).

Richter, J., Ploderer, M., Mongelard, G., Gutierrez, L. and Hauser, M-T. (2017): Role of CrRLK1L Cell Wall Sensors HERCULES1 and 2, THESEUS1, and FERONIA in Growth Adaptation Triggered by Heavy Metals and Trace Elements. Frontiers in Plant Science, 8: 1554. doi: $10.3389 /$ fpls.2017.01554

Robichaud, K., Misra, M., Smith, R. W. and Schneiger, I. A.H. (2021): Adsorption of heavy metals by aquatic plant roots. In book: Water-Rock Interaction, 934 p. doi: 10.1201/ 9780203734049

Seregin, I. V., Kozhevnikova, A. D. (2008): Roles of root and shoot tissues in transport and accumulation of cadmium, lead, nickel, and strontium. Russian Journal of Plant Physiology, 55(1): 1-22. doi: $10.1134 /$ S1021443708010019

SergienKo, L. A. (2008): Flora and vegetation of the Arctic coasts and adjacent territories. Publishing house of PertSU, Petrozavodsk, 225 p. (In Russian).

Sergienko, L. A., Dyachkova, T. Yu. and Androsova, V. I. (2017): Habitat characteristics and population structure of Triglochin maritima L. (Juncaginaceae) in the intertidal zone of the littoral of the White Sea. Proceedings of Petrozavodsk State University. Ser. Natural and Technical Sciences, 2: 57-63.

Sidorova, V. A., Svyatova, E. N. and Tseits, M. A. (2015): Spatial variability of the properties of marsh soils and their impact on vegetation. Eurasian Soil Science, 48 (3): 223-230. doi: $10.1134 / \mathrm{S} 1064229315030114$

TAN, K. H. (2005): Soil Sampling, preparation and analysis, $2^{\text {nd }}$ Edition. By K. H. Tan. Boca Raton, Florida, USA: Taylor and Francis, 680 p.

Terebova, E. N., Markovskaya, E. F., Androsova, V. I., Galibina, N. A. and Kaipiainen, E. (2017): Potential for Salix schwerinii E. Wolf to uptake heavy metals in the contaminated territories of mining industry in the north-west Russia. Siberian Journal of Forest Science, 1: 74-86.

Terebova, E., Markovskaya, E., Androsova, V., Pavlova, M. and Oreshnikova, N. (2020) Cell wall functional activity and metal accumulation of halophytic plant species Plantago maritima and Triglochin maritima on the White Sea littoral zone (NW Russia). Czech Polar Reports, 10 (2): 169-188. doi: 10.5817/CPR2020-2-14

Tsvelev, N. N. (2000): Keys to vascular plants of Northwestern Russia (Leningrad, Pskov, Novgorod regions). Publishing house of SPKhFA, Sankt-Petersburg, 781 p. (In Russian).

VAN Osten, M. J., MAGGiO, A. (2015): Functional biology of halophytes in the phytoremediation of heavy metal contaminated soils. Environmental and Experimental Botany, 111: 135-146. doi: 10.1016/j.envexpbot.2014.11.010

Vorobeva, L. A. (2006): Theory and practice of chemical analysis of soils. GEOS Publishers, Moscow, 400 p. (In Russian)

Wali, M., Gunse, B., Lugany, M., Corrales, I., Abdelly, C., Poschenrieder, C. and Ghnaya, T. (2016): High salinity helps the halophyte Sesuvium portulacastrum in defense against Cd toxicity by maintaining redox balance and photosynthesis. Planta, 244(2): 333-346. doi: 10.1007/s00425-016-2515-5

WANG, Y. J., Zhou, L. M., ZHENG, X. M., QIAN, P. and WU, Y.H. (2013): Influence of Spartina alterniflora on the mobility of heavy metals in salt marsh sediments of the Yangtze River 
A. V. SONINA et al.

Estuary, China. Environmental Science and Pollution Research, 20(3): 1675-1685. doi: 10.1007/ s11356-012-1082-y.

YADAV, S. (2010): Heavy Metals Toxicity in Plants: An Overview on the Role of Glutathione and Phytochelatins in Heavy Metal Stress Tolerance of Plants. South African Journal of Botany, 76(2): 167-179. doi: 10.1016/j.sajb.2009.10.007

Zhang, Z.-C., ChEN, B.-X. and QiU, B.-S. (2010): Phytochelatin synthesis plays a similar role in shoots of the cadmium hyperaccumulator Sedum alfredii as in non-resistant plants. Plant Cell Environmental, 33(8): 1248-1255. doi: 10.1111/j.1365-3040.2010.02144.x

ZHENG, J-C, LiU, H-Q, FENG, H. M. and Yu, H-Q. (2016): Competitive sorption of heavy metals by water hyacinth roots. Environmental Pollution, 219: 837-845. doi: 10.1016/j.envpol.2016. 08.001

\section{Web sources / Other sources}

[1] Order of Ministry of Agricultyre of the Russian Federation of Decemder 13, 2016. №. 552. (2016). On the approval of water quality standards for water bodies of fishery value, including the standards of maximum permissible concentrations of harmful substances in the waters of water bodies of fishery value. (In Russian).

[2] State Report on the State of the Evironment of the Republic of Karelia in 2019 (2020). In: A. N. Gromtsev (eds.), Petrozavodsk, 248 p. (In Russian). 